\title{
RUANG PEMBELAJARAN KREATIVITAS DI BSD
}

\author{
Natasha Liunardi ${ }^{1)}$, Nina Carina ${ }^{2)}$ \\ 1) Program Studi S1 Arsitektur, Fakultas Teknik, Universitas Tarumanagara, natashaliunardi@yahoo.com \\ 2) Program Studi S1 Arsitektur, Fakultas Teknik, Universitas Tarumanagara, ninac@ft.untar.ac.id
}

\begin{abstract}
Abstrak
Kegiatan masyarakat sehari-hari hanya dilakukan antara rumah dengan sekolah atau kampus dan tempat kerja. Hal tersebut dapat memicu penat akibat beban kerja, beban pikiran, dan kurangnya aktivitas terlepas dari kesehariannya serta rasa sosial antar sesama karena sibuk dengan kegiatan masing-masing. Tempat ketiga adalah sebuah ruang publik yang netral untuk mewadahi kebutuhan dalam melepas beban kerja atau sekolah, dan bersosialisasi, berinteraksi, bertukar pikiran antar sesama masyarakat tanpa memandang adanya perbedaan latar belakang. Ruang pembelajaran kreativitas di BSD adalah sebuah ruang ketiga yang merupakan wadah edukasi - rekreasi berbasis seni dan dapat menjadi jawaban permasalahan tersebut. Dengan dilengkapi sarana bermain, belajar, berkumpul, dan bersantai yang masih berkaitan dengan program utama, tempat ini ditujukan bagi masyarakat sekitar dari seluruh kalangan tanpa adanya batasan umur. Proyek ini bertemakan kreativitas seni yang didapat dari jawaban permasalahan kawasan terpilih yaitu BSD, Tangerang Selatan serta hubungannya dengan tempat ketiga yang cukup erat. Metode yang digunakan dalam merancang tempat ketiga ini adalah spatial archetype grid yang memiliki sifat yang sama dengan karakteristik tempat ketiga yaitu terbuka dan tidak terikat serta netral. Metode ini merupakan bagian dalam konsep perancangan dalam menciptakan tempat ketiga dengan memperhatikan hubungan antar ruang dan program yang saling berkaitan satu dengan yang lainnya.
\end{abstract}

Kata kunci: kegiatan; kreativitas; masyarakat; tempat ketiga; spatial archetype grid

\begin{abstract}
Daily activities of the community are only carried out between home with college or school and workplace. This can trigger fatigue because burdens of thought and workload, and there is no activities separated from their daily lives and elimintas the social sence between the communities because they're busy with their activities. Third place is a neutral public space to accommodate the need for release work or school burdens and to socialize, interacting, and to share their views among community without looking at the difference in background. BSD creative learning space is a third place with an educational recreation forum and can be the answer to these problems. Equipped with play, study, gathering, and leisure who still related to main program being intended for the community around of all without age restrictions. This project has theme of art creativity as a result of answering the problems in BSD, South Tangerang and those are close to third place. The method that used in designing third place is spatial archetype grid has the same characteristics as third place such as openness, not bound, and neutral. This method is a part of the concept of design in creating third place by taking into account the relationship between space and programs are intertwined with each other.
\end{abstract}

Keywords: activities; community; creativity; third place; spatial archetype grid

\section{PENDAHULUAN}

Berkembangnya suatu komunitas atau suatu bangsa di masa depan sangat bergantung pada kontribusinya pendidikan. Shane (1984: 39), sangat yakin bahwa pendidikan dapat memberikan kontribusi pada kebudayaan di hari esok. Pendapat yang sama juga terdapat dalam penjelasan 
Umum Undang-Undang Republik Indonesia Nomor 20 Tahun 2003 tentang sistem pendidikan Nasional (UU No. 20/2003), yang antara lain menyatakan: "Manusia membutuhkan pendidikan dalam kehidupannya. Pendidikan merupakan usaha agar manusia dapat mengembangkan potensi dirinya melalui proses pembelajaran dan atau cara lain yang dikenal dan diakui oleh masyarakat".

Dalam pendidikan terjadi proses pengembangan potensi manusiawi dan proses pewarisan kebudayaan. Setiap individu peserta didik berhak untuk mengembangkan dirinya sesuai potensinya secara alamiah, wajar, dan tanpa tekanan. Pada masa sekarang ini, pendidikan tidak hanya di dapat pada pendidikan formal, tetapi adanya pendidikan non-formal sebagai pelengkap dalam pengembangan potensi diri. Pendidikan non-formal ini dapat dijumpai seperti kursus, kelompok belajar, maupun pusat kegiatan masyarakat.

Pembelajaran zaman ini tidak hanya mengenai ilmu-ilmu sosial tetapi juga bisa dalam seni yang pada dasarnya juga merupakan sebuah pembelajaran. Seiring berkembangnya zaman, kebutuhan manusia semakin bertambah termasuk dari segi kebutuhan untuk berekreasi. Jenis rekreasi sekaligus sebagai sarana pembelajaran menjadi daya tarik tersendiri bagi masyarakat, seperti sarana rekreasi dan edukasi. Keseharian warga yang beraktivitas hanya di rumah (first place) dan sekolah, universitas, dan kantor (second place) mengakibatkan masih kurangnya sarana bersosialisasi masyarakat baik dalam aspek edukasi maupun rekreasi.

Dari hasil studi di atas, maka dirancanglah sebuah wadah/ third place untuk mengakomodasi kegiatan masyarakat. Kegiatan yang dilakukan selama bersosialisasi dapat berupa perkumpulan masyarakat dalam workshop atau seminar dan juga tempat belajar dengan sifat rekreatif, tetapi pengunjung yang datang tidak hanya sebatas orang yang ingin datang untuk mengikuti kelas workshop atau seminar, kehadiran publik juga disambut. Dari hal itu, maka terdapat program di dalam wadah berupa area umum seperti kafe dan restoran serta event space.

Manusia pada umumnya cenderung tidak tertarik untuk datang ke tempat tertutup dan terlihat formal, karena mereka akan merasa kegiatan di dalamnya tidak dapat diikuti oleh seluruh warga. Maka dari itu, wadah ini dirancang secara terbuka yang memberikan persepsi kepada warga bahwa wadah/ bangunan ini dapat didatangi oleh publik. Pengunjung akan merasa bahwa bangunan ini hanyalah sebuah tempat untuk berekreasi dan menyalurkan ketertarikan mereka terhadap sebuah kegiatan, tetapi tanpa mereka sadari kegiatan-kegiatan tersebut mengasah potensi dan kemampuan dalam mencapai kesejahteraan masyarakat untuk pengembangan kota yang lebih maju.

\section{KAJIAN LITERATUR}

\section{Third Place}

Third Place adalah tempat publik untuk menuangkan kegiatan/aktivitas masyarakat, tetapi masyarakat masih kurang menaruh perhatian pada third place. Selain itu, third place juga dapat menjadi tempat untuk berelaksasi dan melepas stres serta untuk tempat berlindung dan melakukan aktivitas untuk menambah pengalaman dan relasi sosial yang mungkin tidak dapat ditemukan di tempat lain. Third place dalam karakteristiknya mengajak pengguna untuk merasakan perbedaan dengan rumah dan kerja secara signifikan dan kontras. Adanya interaksi, kehidupan komunitas, fasilitas untuk relaksasi di publik dan pertemuan antara teman, keluarga, serta orang-orang yang baru atau pertama kali kenal atau bertemu.

Oldernburg (1989) dalam bukunya Open Architecture membuat 7 karaktetistik Third Place:

a. Neutral Ground

Netral merupakan kata yang cocok untuk mendeskripsikan third place karena tidak terikat dengan hal-hal politik, sosial sehingga semua orang dapat datang dan pergi.

b. They are Level (Leveler)

Tidak adanya status individu dalam komunitas di third place. Status sosial dan ekonomi dianggap tidak ada dan peraturan tertentu yang membatasi orang untuk datang.

c. Conversation is the main activity 
Playful dan percakapan yang menarik adalah fokus utama dari aktivitas di third place. Percakapan yang ringan dan friendly adalah point yang dijunjung tinggi.

\section{d. Accessibility and accommodation}

Akses yang mudah dan terbuka bagi pengunjung atau pengguna. Menyediakan akomodasi dan akses bagi seluruh kriteria sehingga pengguna merasa kebutuhannya terpenuhi.

e. The regulars

Adanya pengunjung regular yang datang sehingga dapat menciptakan suasana dan karakteristik third place. Dapat menarik pengunjung baru dan mengembangkan menjadi tempat yang lebih hidup.

f. A low profile

Third place tidak megah tetapi lebih memiliki suasana seperti rumah sehingga semua individu dapat merasakan perbedaan tiap hidup.

g. The mood is playful

Tidak adanya ketegangan dalam percakapan tetapi lebih relaks dan enjoyable sama hal nya dengan suasana yang tercipta.

\section{Open Architecture}

The third place di dalam konteks kota dimana di dalamnya terdapat program utama yang didukung oleh program-program lain yang mampu melayani kebutuhan masyarakat kota modern yang menuntut kehidupan yang serba cepat, dinamis dan efisien yang kemudian diajukan sebagai proposal arsitektur yang dinamakan open architecture. Open architecture merupakan the third place bagi masyarakat kota, yang berfungsi sebagai ruaag antara, ruang yang bukan tempat tinggal dan bukan tempat kerja. Open architecture merupakan sistem yang terbuka dan mampu beradaptasi dengan kepentingan terpilih (selected). Konflik-konflik yang terjadi dari masyarakat kota dapat dipecahkan atau dilakukan pendekatan melalui rangkaian pendekatan disain (design approach) dan juga strategi perancangan (design strategy). Open architecture menjadi kesempatan untuk menciptakan sebuah platform arsitektur yang dapat dikombinasikan dengan berbagai macam keadaan dan kondisi masyarakat dalam hal ini masyarakat perkotaan Jakarta atau kota besar lainnya.

\section{Pembelajaran}

Pengertian Pembelajaran adalah proses interaksi peserta didik dengan pendidik dan sumber belajar pada suatu lingkungan belajar. Pembelajaran merupakan bantuan yang diberikan pendidik agar dapat terjadi proses pemerolehan ilmu dan pengetahuan, penguasaan kemahiran dan tabiat, serta pembentukan sikap dan kepercayaan pada peserta didik. Dengan kata lain, pembelajaran adalah proses untuk membantu peserta didik agar dapat belajar dengan baik.

Pembelajaran mempunyai pengertian yang mirip dengan pengajaran, walaupun mempunyai konotasi yang berbeda. Pembelajaran adalah pemberdayaan potensi peserta didik menjadi kompetensi. Kegiatan pemberdayaan ini tidak dapat berhasil tanpa ada orang yang membantu. Dalam Undang-Undang No. 20 Tahun 2003 Tentang Sistem Pendidikan Nasional pasal 1 ayat 20 dinyatakan bahwa pembelajaran adalah proses interaksi peserta didik dengan pendidik dan sumber belajar pada suatu lingkungan belajar.

\section{Pendidikan}

Pendidikan merupakan kebutuhan sepanjang hayat. Pendidikan sangat penting artinya, sebab tanpa pendidikan manusia akan sulit berkembang dan bahkan akan terbelakang. Dengan demikian pendidikan harus betul-betul diarahkan untuk menghasilkan manusia yang berkualitas dan mampu bersaing, di samping memiliki budi pekerti yang luhur dan moral yang baik. Di era informasi yang serba instan ini setiap masyarakat pasti membutuhkan pusat informasi dan pengetahuan. Pendidikan merupakan suatu proses yang sangat kompleks dan berjangka 
panjang, di mana berbagai aspek yang tercakup dalam proses saling erat berkaitan satu sama lain dan bermuara pada terwujudnya manusia yang memiliki nilai hidup, pengetahuan hidup dan keterampilan hidup.

Empat pilar pendidikan sekarang dan masa depan yang dicanangkan oleh UNESCO yang perlu dikembangkan oleh lembaga pendidikan formal, yaitu:

- Learning to Know (belajar untuk mengetahui),

Dalam rangka merealisasikan Learning to Know, Guru berfungsi sebagai fasilitator. Di samping itu guru dituntut untuk dapat berperan sebagai teman sejawat dalam berdialog dengan siswa dalam mengembangkan penguasaan pengetahuan maupun ilmu tertentu.

- Learning to Do (belajar untuk melakukan sesuatu)

Learning to do akan bisa berjalan jika sekolah memfasilitasi siswa untuk mengaktualisasikan keterampilan yang dimilikinya, serta bakat dan minatnya. Keterampilan dapat digunakan untuk menopang kehidupan seseorang bahkan keterampilan lebih dominan daripada penguasaan pengetahuan dalam mendukung keberhasilan kehidupan seseorang.

- Learning to be (belajar untuk menjadi seseorang)

Learning to be erat hubungannya dengan bakat dan minat, perkembangan fisik dan kejiwaan, tipologi pribadi anak serta kondisi lingkungannya. Bagi anak yang agresif, proses pengembangan diri akan berjalan bila diberi kesempatan cukup luas untuk berkreasi. Sebaliknya bagi anak yang pasif, peran guru sebagai pengarah sekaligus fasilitator sangat dibutuhkan untuk pengembangan diri siswa secara maksimal.

- Learning to live together (belajar untuk menjalani kehidupan bersama).

Kebiasaan hidup bersama, saling menghargai, terbuka, memberi dan menerima (take and give), perlu ditumbuh kembangkan. Kondisi seperti ini memungkinkan terjadinya proses learning to live together.

Dari 4 pilar yang dicanangkan UNESCO sudah diterapkan dalam pembelajaran di sekolah, tetapi dalam proyek ini diharapkan dapat lebih menonjolkan Learning to live together. Kebersamaan dengan masyarakat dalam proses belajar dapat menambah pengetahuan dan dapat menumbuhkan kota menjadi kota yang berintegrasi tinggi dan masyarakat yang berpengetahuan luas. Menciptakan kota yang maju bagi masa mendatang dengan informasi dan komunikasi teknologi.

\section{Kreativitas}

Kreativitas dari segi operasional mencakup kelancaran, keluwesan, orisinalitas dalam berpikir. Kreativitas juga dapat dilihat dari konsep 4P yaitu pribadi, pendorong, proses dan produk. Kreativitas sebagai pribadi menunjukkan bahwa kreativitas dimiliki setiap orang. Sebagai pendorong, kreativitas diartikan sebagai seberapa besar lingkungan dapat memberikan bagian dalam memberikan dorongan. Proses menunjukkan pada bagaimana suatu hasil dapat dinikmati. Produk menunjukkan bahwa setiap hasil kreatif dapat dinikmati dan bermakna. Kemampuan kreatif seseorang sangat tergantung dari faktor dalam diri dan luar diri. Oleh karena itu sebagaimana layaknya bakat dan minat, kemampuan kreatif seseorang juga perlu dikembangkan. Oleh karenanya sumber-sumber kreativitas seperti kognitif, kepribadian, motivasional dan lingkungan perlu dikembangkan semaksimal mungkin.

\section{METODE}

\section{Metode Spatial Archetype Grid}

Metode perancangan yang digunakan pada proyek ini adalah metode pengumpulan data, analisis dan sintesis melalui konsep spatial archetype grid berdasarkan Mimi Lobell (1983: 6982) dalam Gunawan (2000: hal 57-63). Metode ini menjelaskan bahwa tidak adanya batasan yang mengikat dalam ruang dan tidak adanya hirarki yang berperan di dalamnya. Metode ini dipilih karena konsep yang terbuka dan dapat diakses oleh semua orang adalah tujuan utama dari proyek ini. 

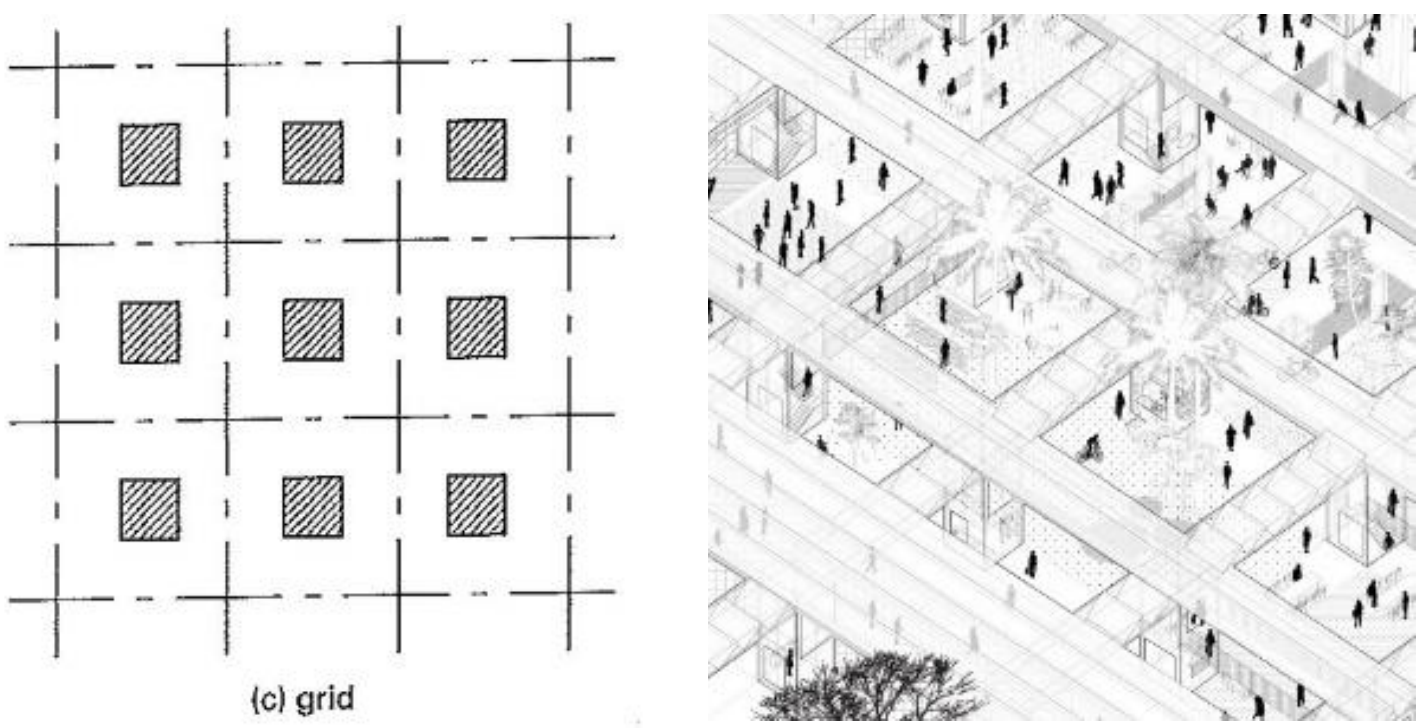

(c) grid

Gambar 1. Metode spatial archetype grid Sumber : Tjahjono, 2000

Metode ini sangat cocok diterpakan pada perancangan third place karena ruang yang netral sesuai dengan karakteristik sebuah third place. Terlihat sebagai ruang dengan fungsi utama dan penunjang, tetapi pada kenyataannya ruang akan dapat digunakan dan memiliki manfaat yang setara.

\section{DISKUSI DAN HASIL}

\section{Data Tapak}

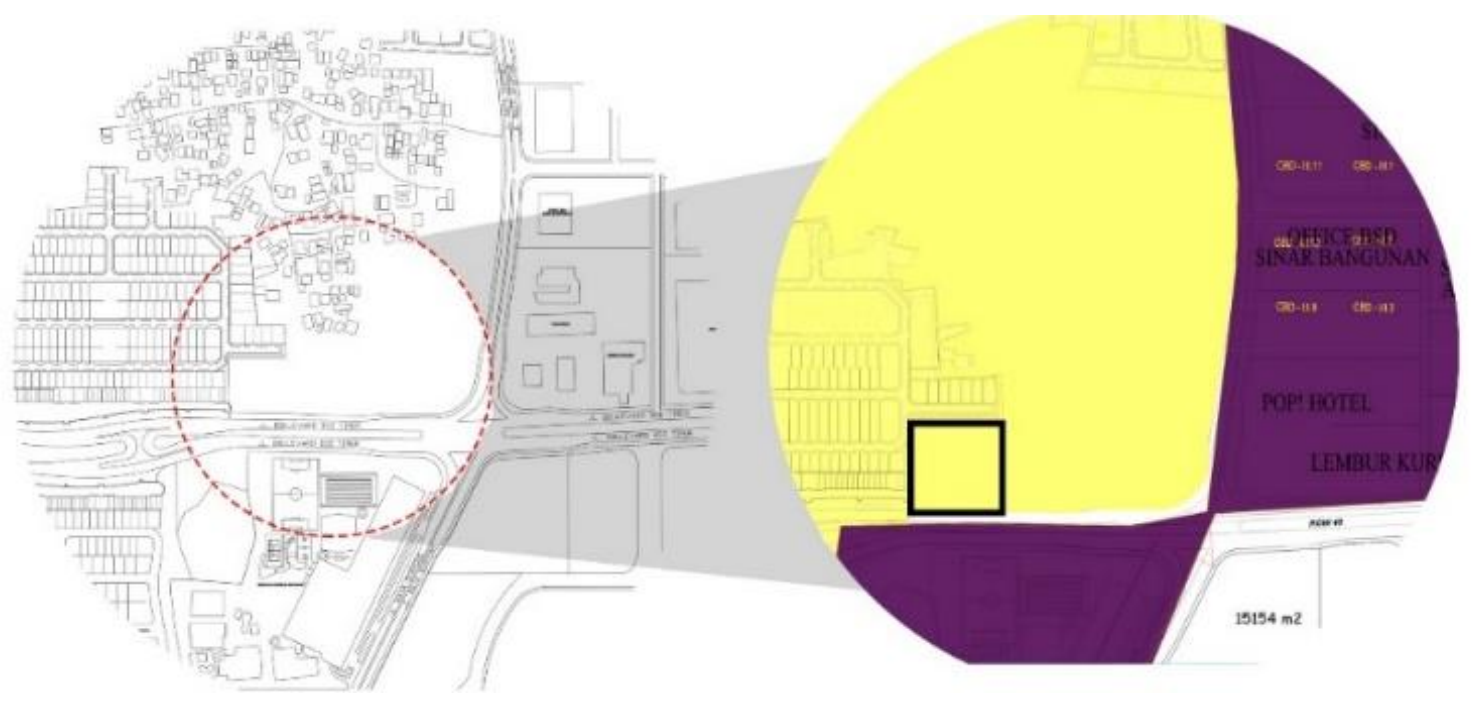

Gambar 2. Zonasi Tapak

Sumber: Penulis, 2019

Tapak memiliki Peraturan Pembangunan sebagai berikut:

Luas Tapak: $3.869 \mathrm{~m} 2$

Koefisien Dasar Bangunan (KDB): 60\% $=2321.4 \mathrm{~m} 2$

Koefisien Dasar Hijau (KDH): $20 \%=773,8 \mathrm{~m} 2$

Koefisien Luas Bangunan (KLB): $1.2=4642,8 \mathrm{~m} 2$

Ketinggian Bangunan (KB): 4 Lantai

Garis Sepadan Bangunan: $8 \mathrm{~m}$

Zonasi: Perumahan diizinkan untuk pembangunan taman rekreasi 


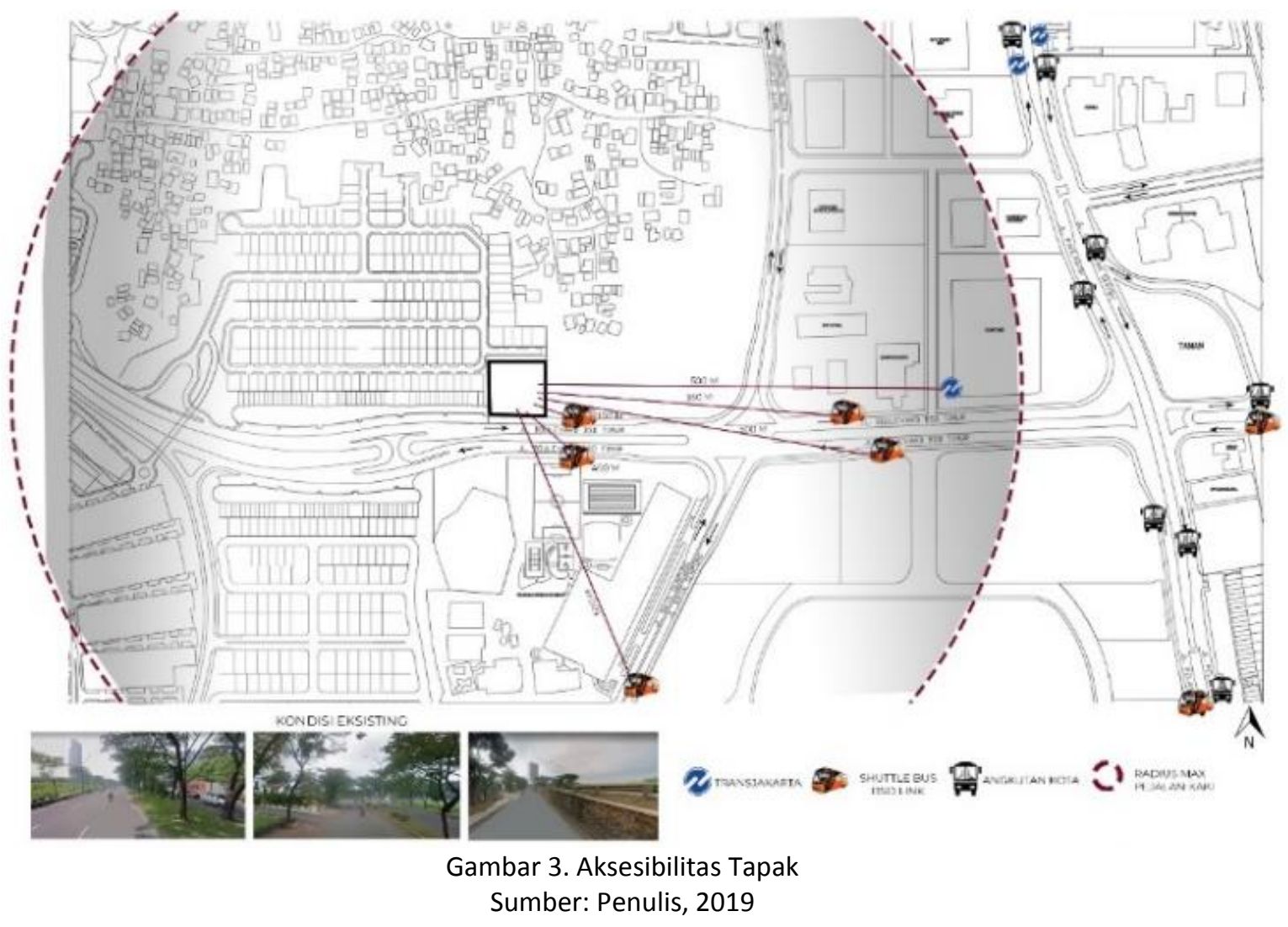

Pencapaian ke Tapak dapat dengan mudah dijangkau menggunakan shuttle bus BSD yang berhenti langsung di depan tapak, atau dapat menggunakan Transjakarta dan berjalan kaki sejauh $500 \mathrm{~m}$ atau melanjutkannya dengan shuttle bus. 


\section{Skema Desain}

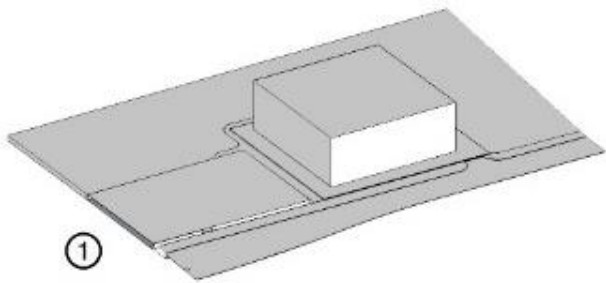

Bentuk dasar bangunan adalah persegi yang di capat dari bentuk tapak

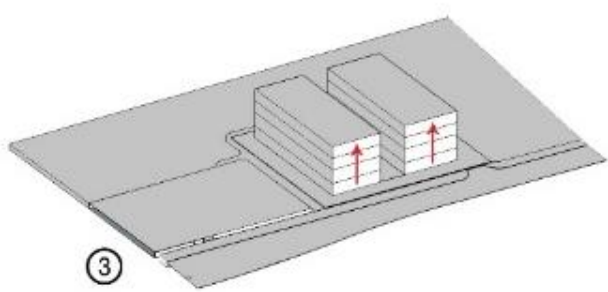

Membagi bangunan menjadi 4 lantai untuk memaksimalkan ketinggian bangunan tapak

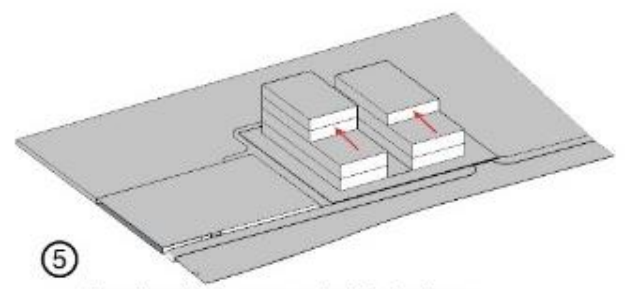

Visualisasi bangunan dari sisi selatan berundak dengan tujuan pandangan tidak terblok oleh bangunan dan bangunan nyaman dalam skala manusia

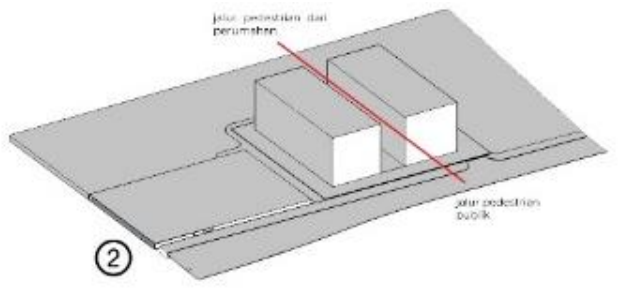

Pemberian jalur pedestrian sepanjang bangunan sehingga pedestrian dapat masuk dari 2 arah

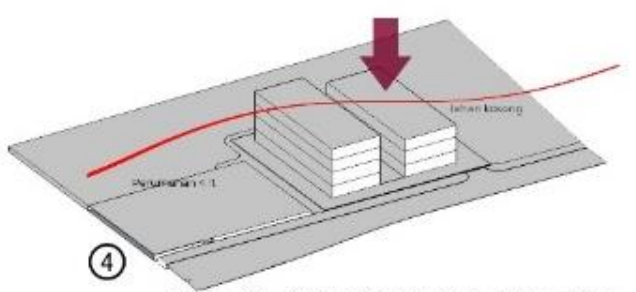

Pada sisi timur bangunan merupakan lahan kosong dan sisi barat perumahan 4 lantai sehingga bangunan sisi timur akan lebih pendek untuk menjawab skyline sekitar

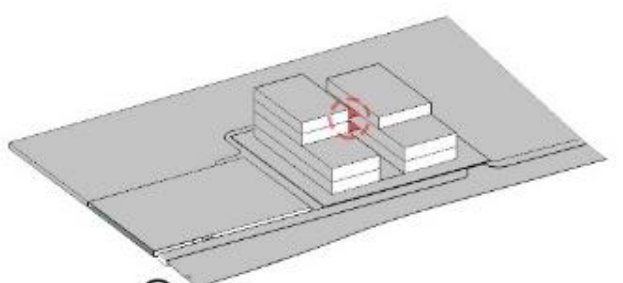

(6) Pemberian jembatan pada lanta 2 dan 3 sebagai penghubung massa bangunan.

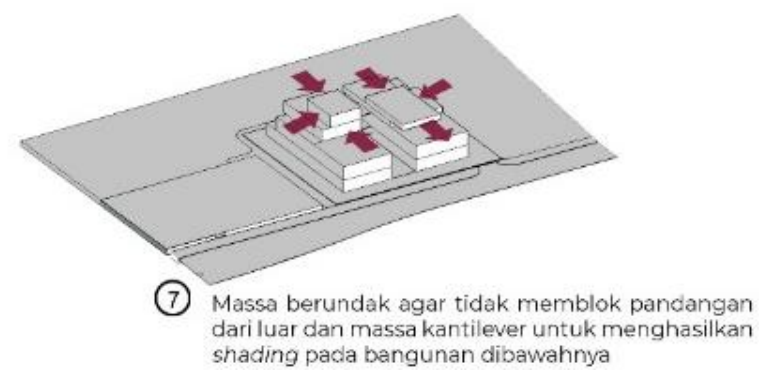

Gambar 4. Skema Desain

Sumber: Penulis, 2019

Berikut merupakan hasil rancangan berupa denah, tampak, dan potongan. 


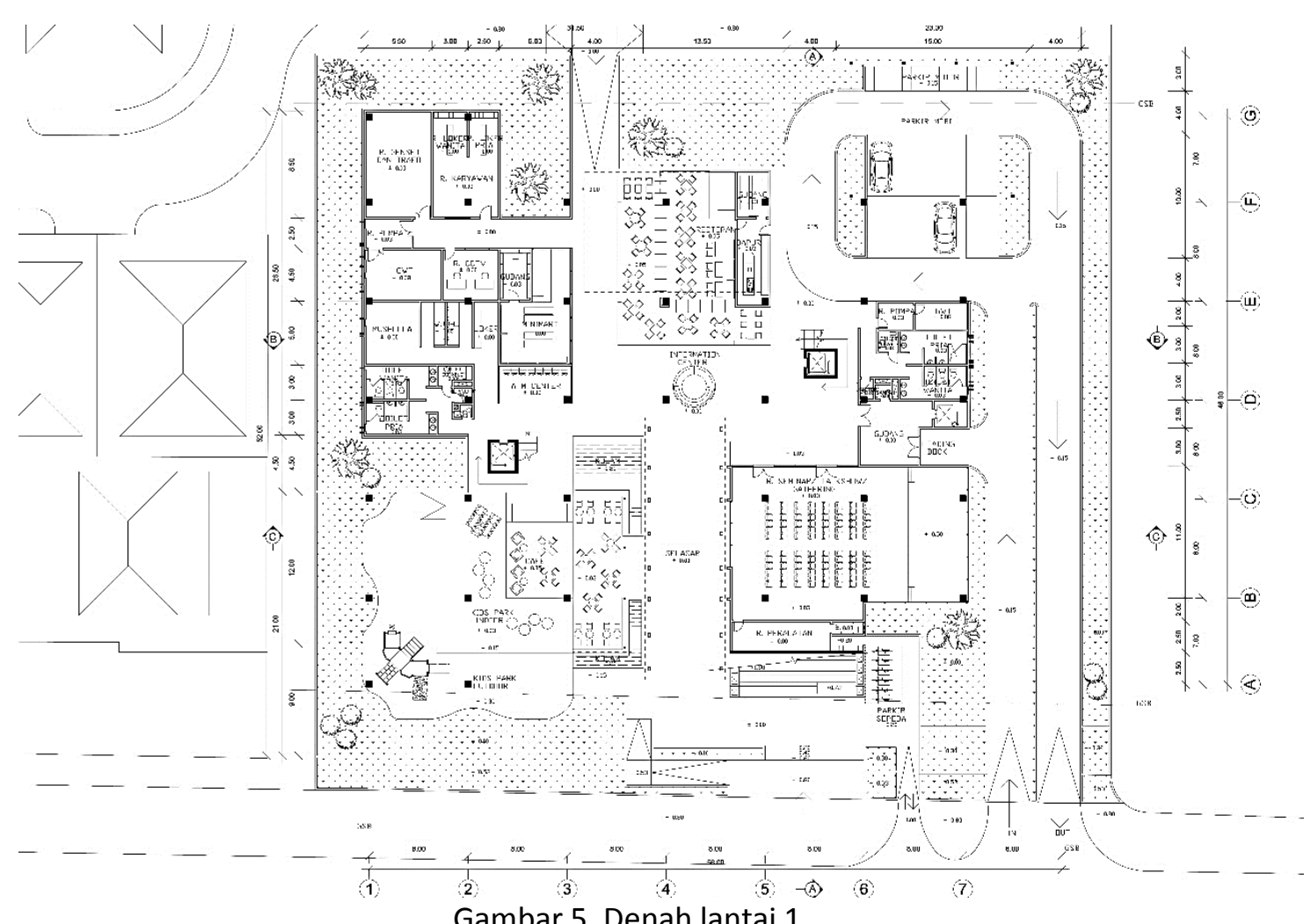

Sumber: Penulis, 2019
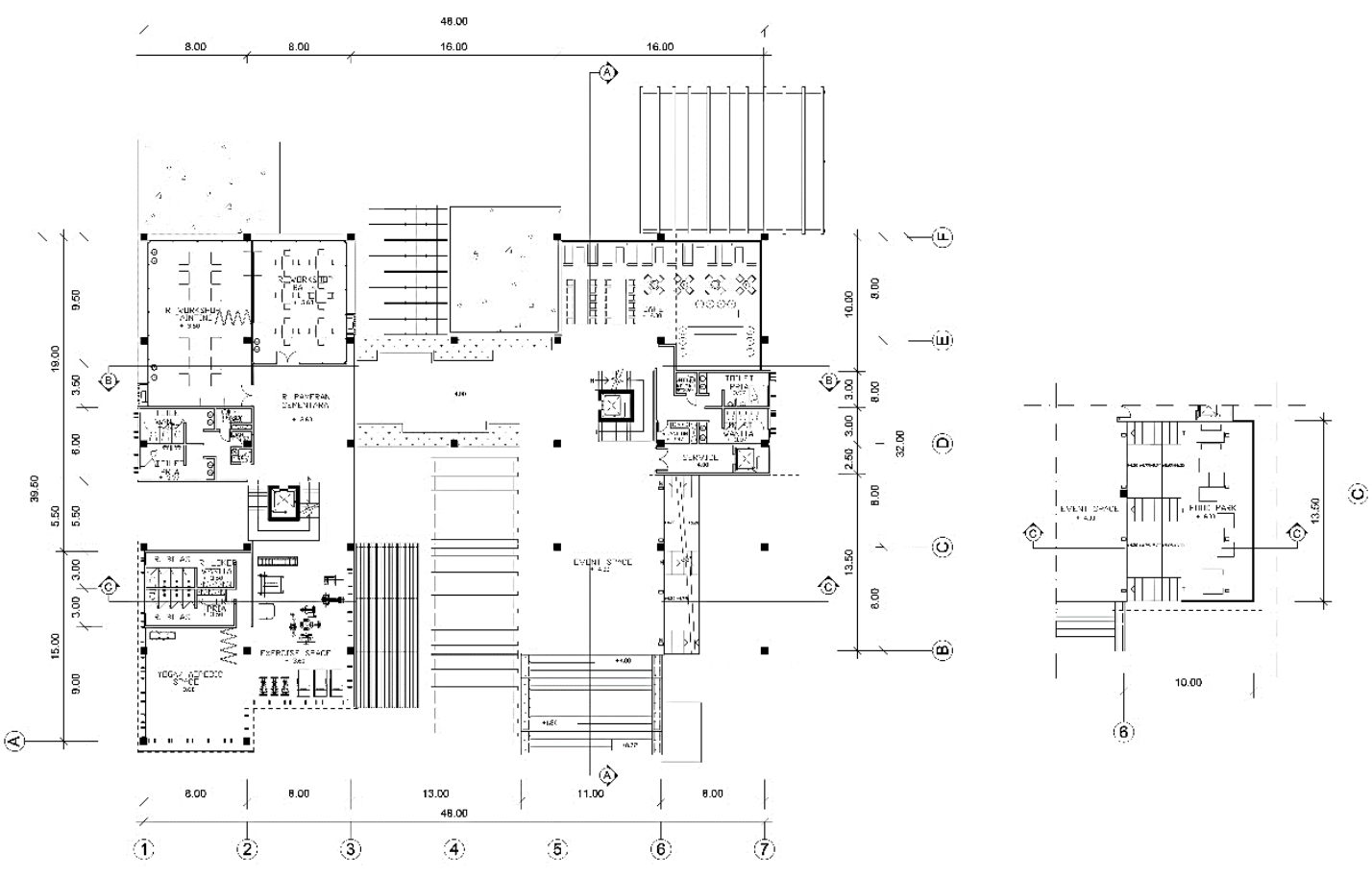

Gambar 6. Denah lantai 2 dan 2A

Sumber: Penulis, 2019 


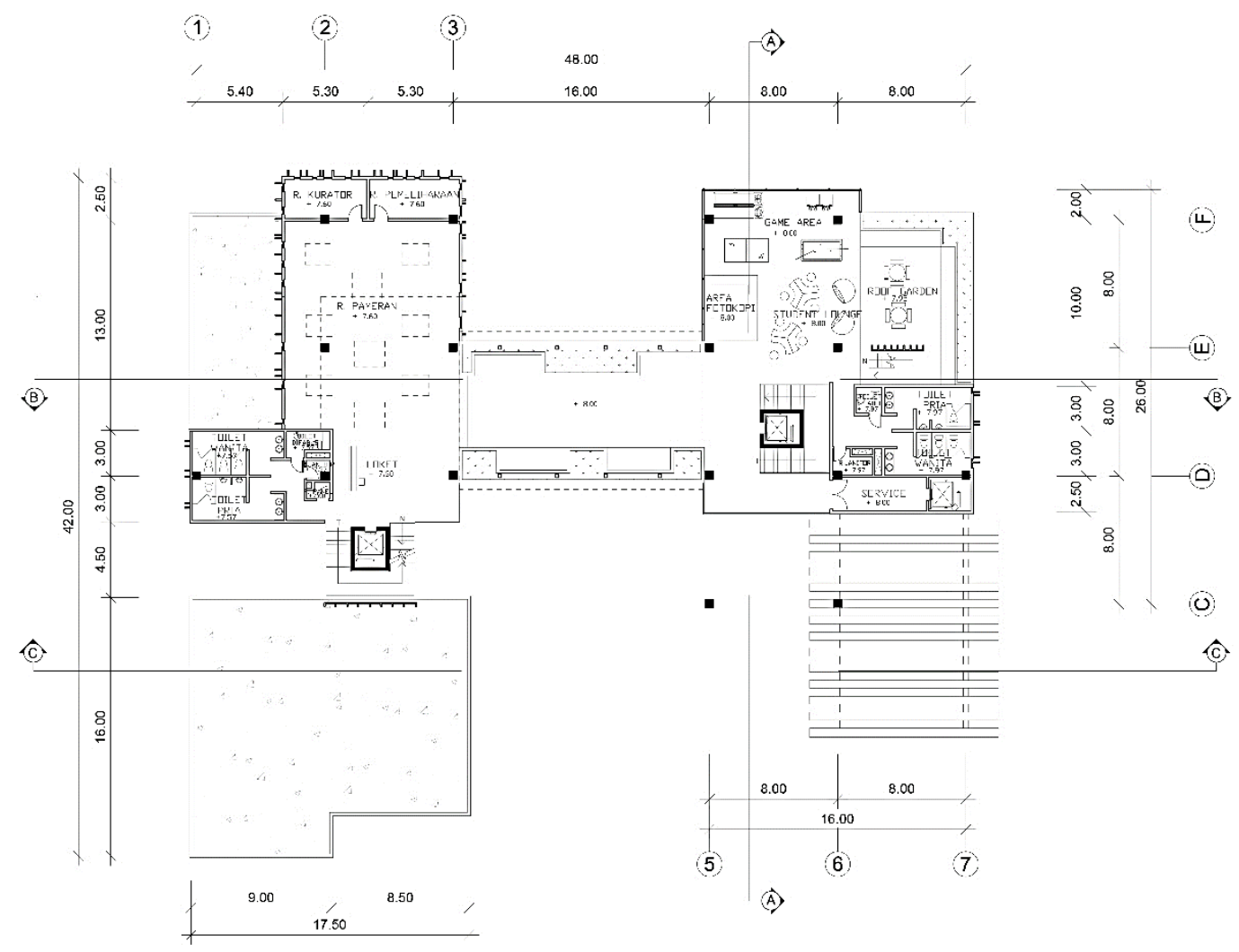

Gambar 7. Denah lantai 3

Sumber: Penulis, 2019

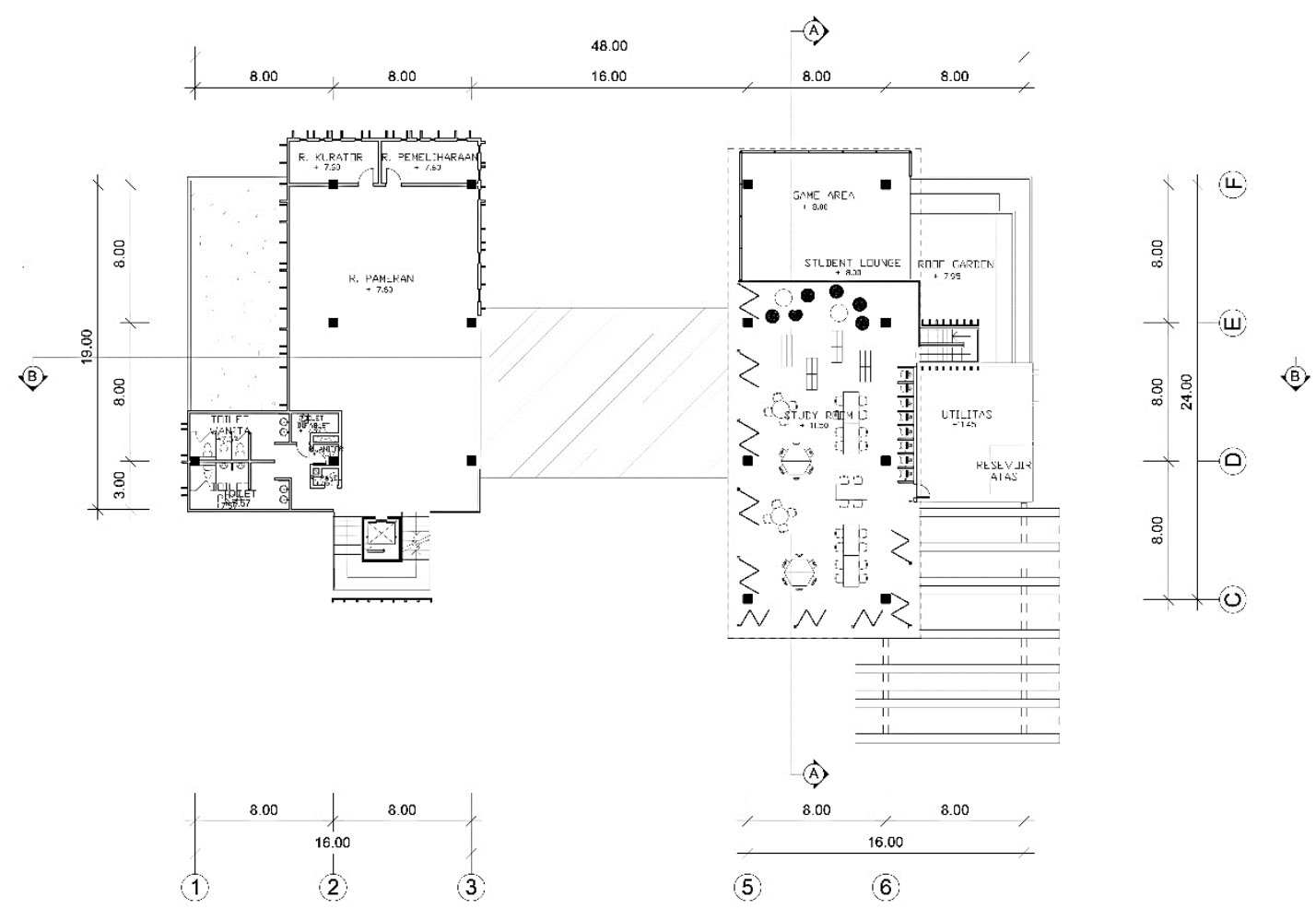

Gambar 8. Denah lantai mezanin

Sumber: Penulis, 2019 

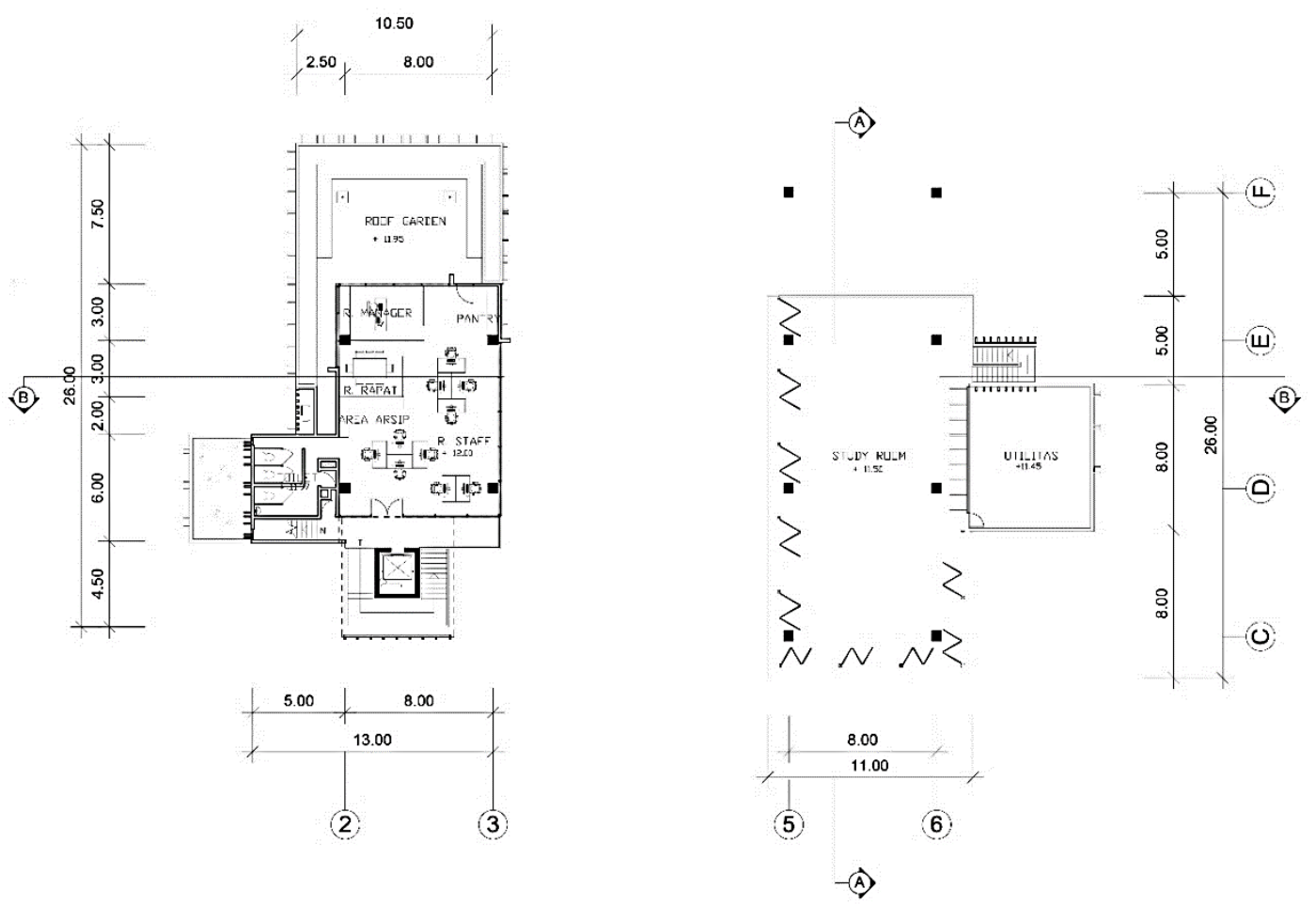

Gambar 9. Denah lantai 4

Sumber: Penulis, 2019

'Dilihat pada denah tiap lantai bangunan memiliki program edukasi seperti ruang workshop, ruang seminar, ruang belajar bagi mahasiswa/ pelajar dan ditunjang dengan ruang event, kafe, restoran, tempat berolahraga yang menjadikan bangunan ini sebagai wadah bagi masyarakat dalam bersosialisasi.

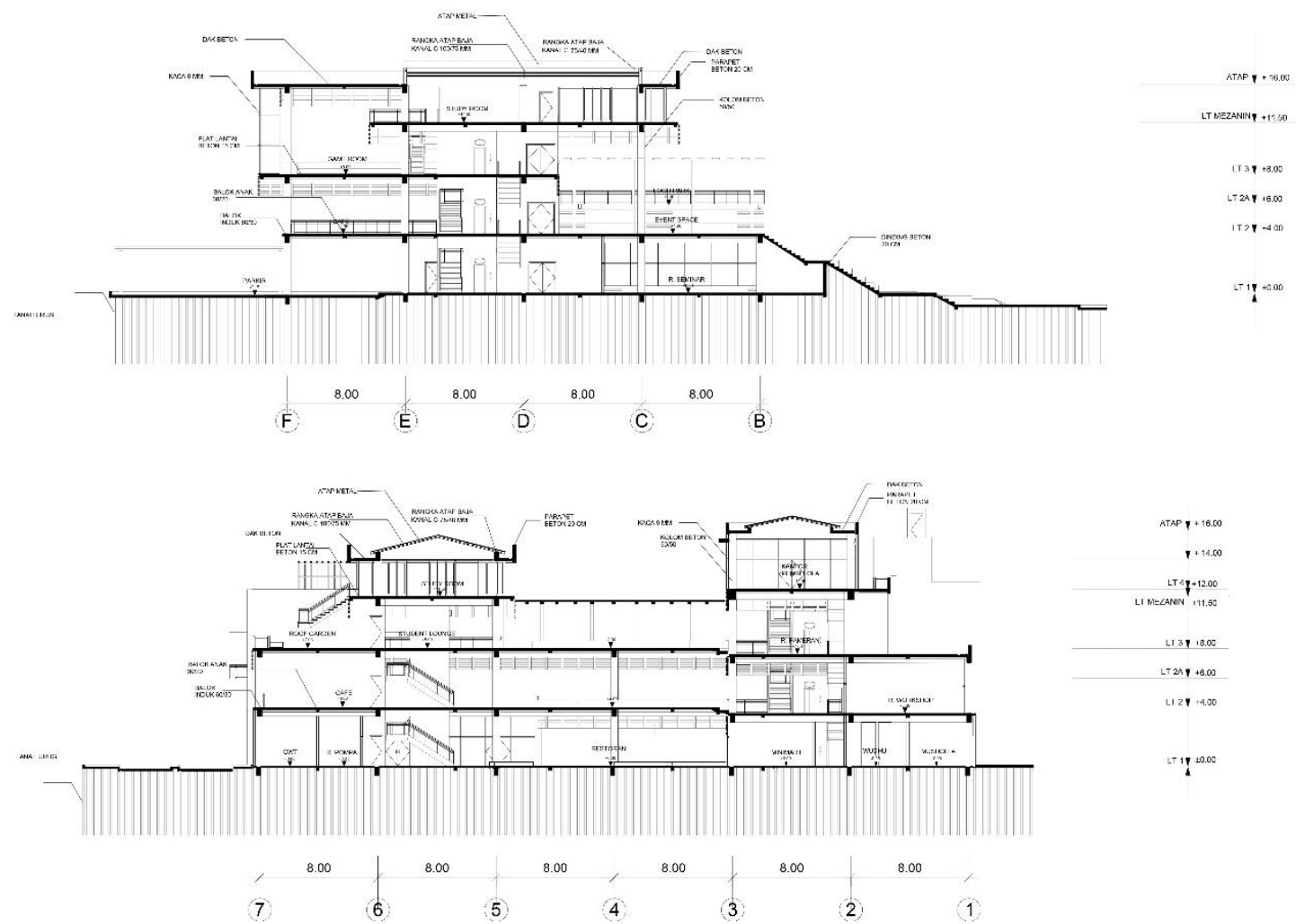

Gambar 10. Potongan A-A dan B-B

Sumber: Penulis, 2019 


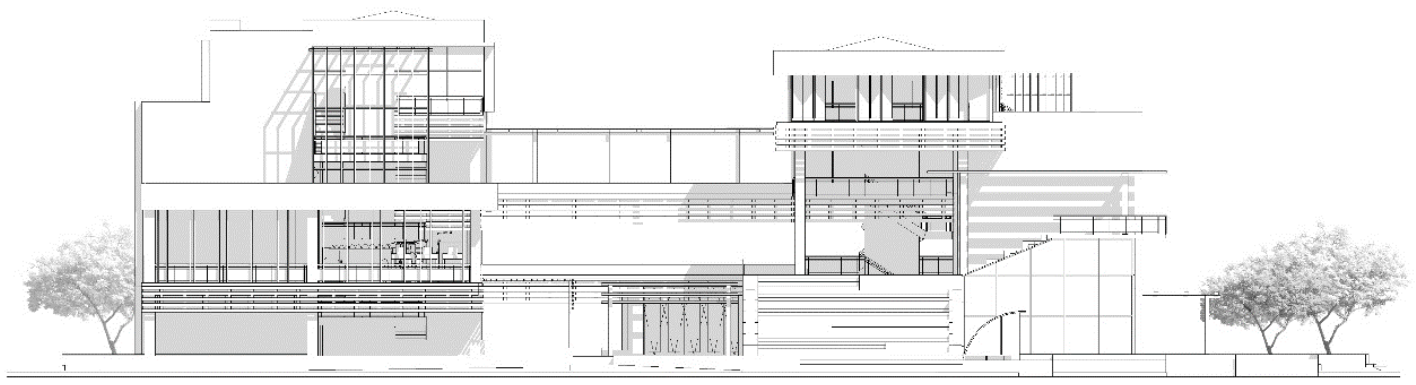

Tampak Depan

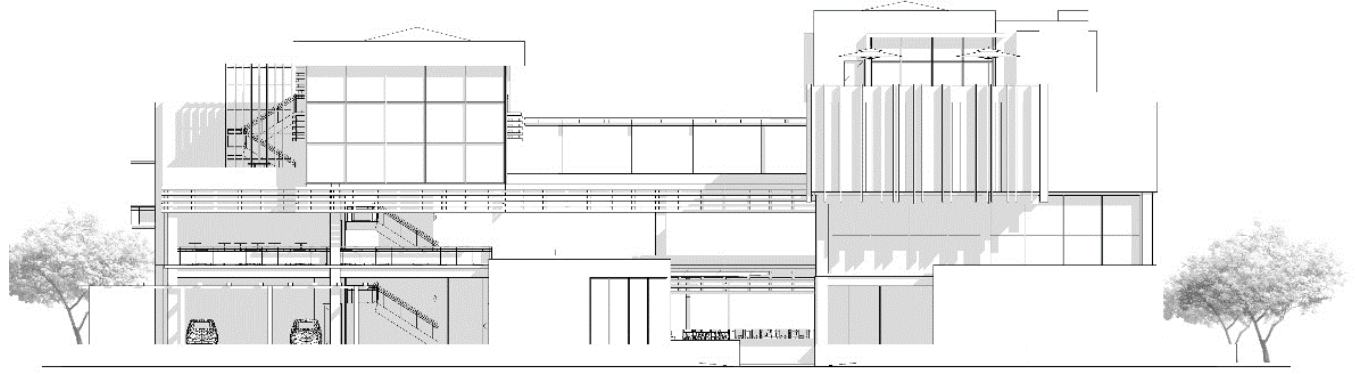

Tampak Belakang

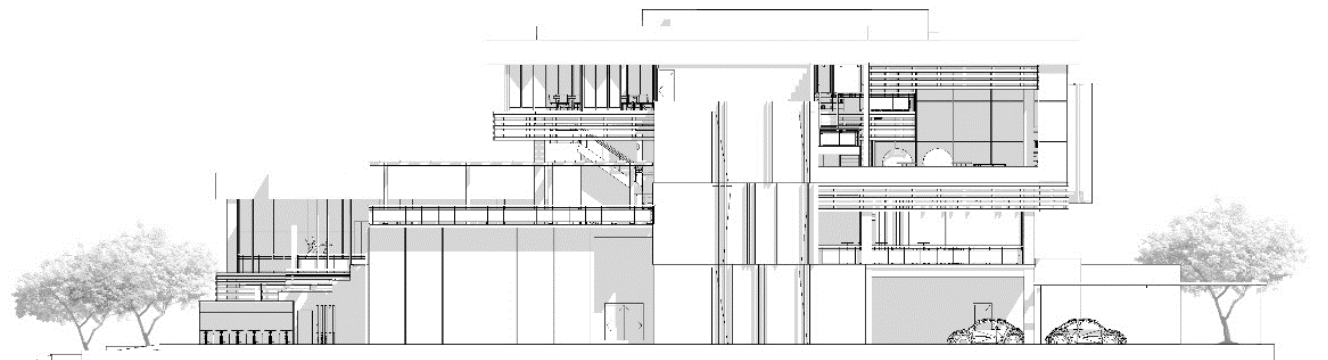

Tampak Samping Kanan

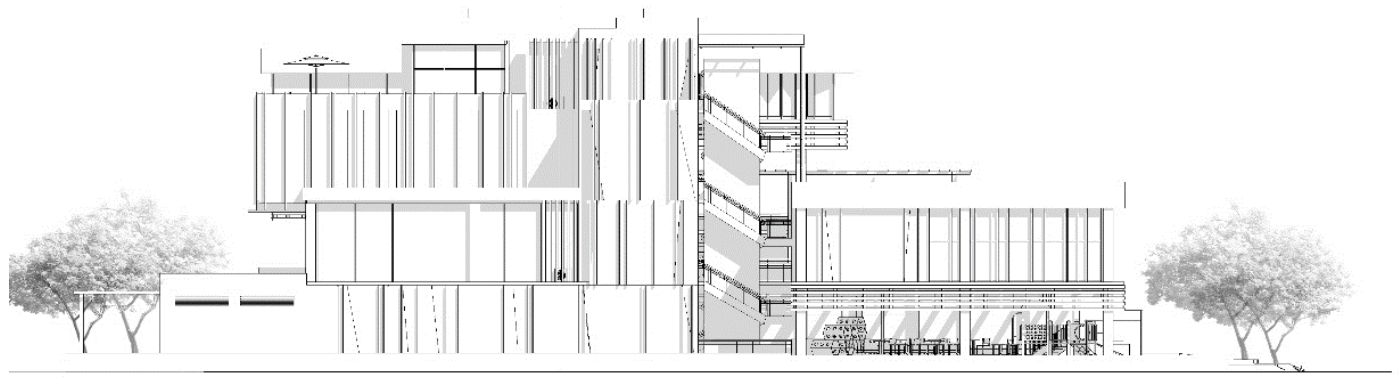

Tampak Samping Kiri

Gambar 11. Tampak Bangunan

Sumber: Penulis, 2019 


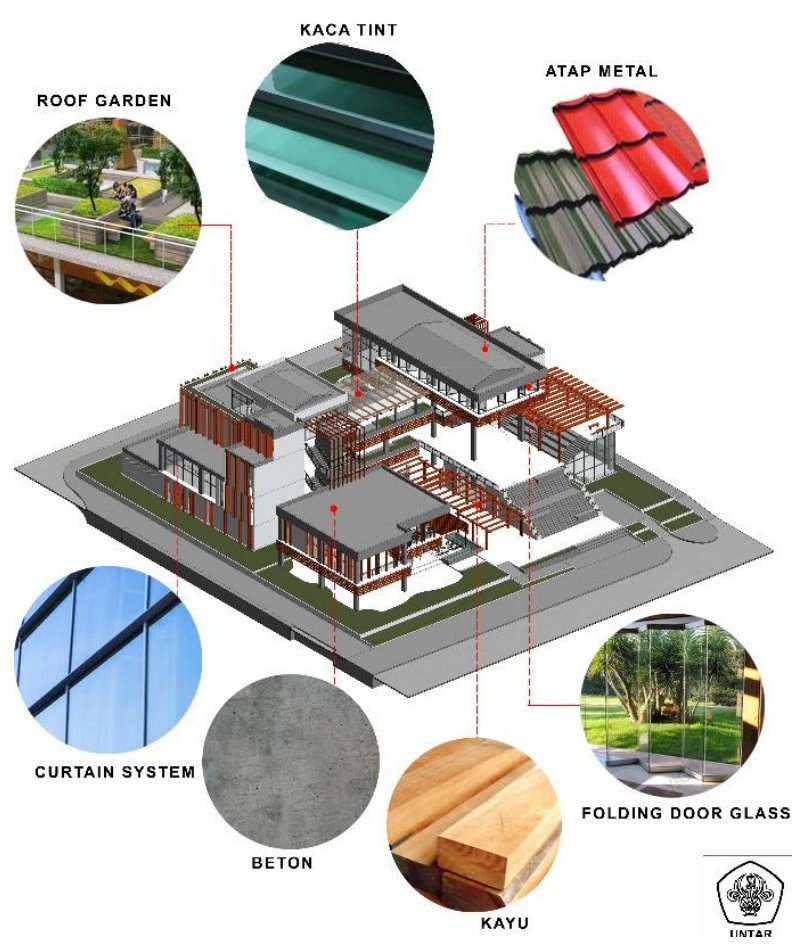

Gambar 12. Material Bangunan

Sumber: Penulis, 2019

Struktur yang digunakan pada bangunan ini adalah struktur beton pada kolom, balok, lantai dan dinding bata. Adapun kaca yang digunakan adalah kaca tint sehingga cahaya matahari yang masuk dapat diserap agar ruangan yang terkena matahari tidak panas. Penggunaan kisi kayu pada tiap sisi bangunan dimaksudkan untuk membiaskan cahaya matahari yang menyinari ruangan.

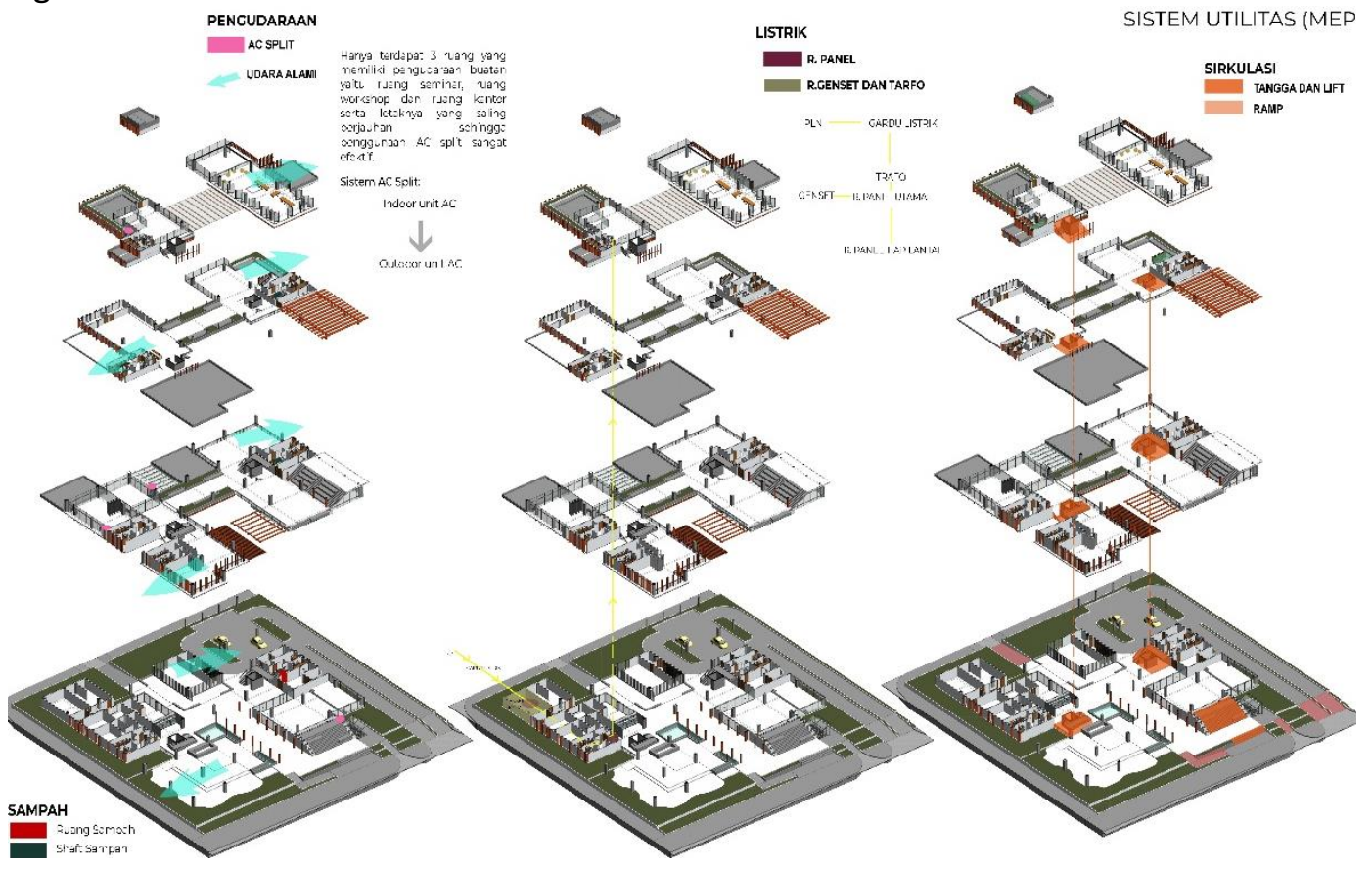

Gambar 13. Sistem Mekanikal Elektrikal dan Sirkulasi dalam Bangunan Sumber: Penulis, 2019 


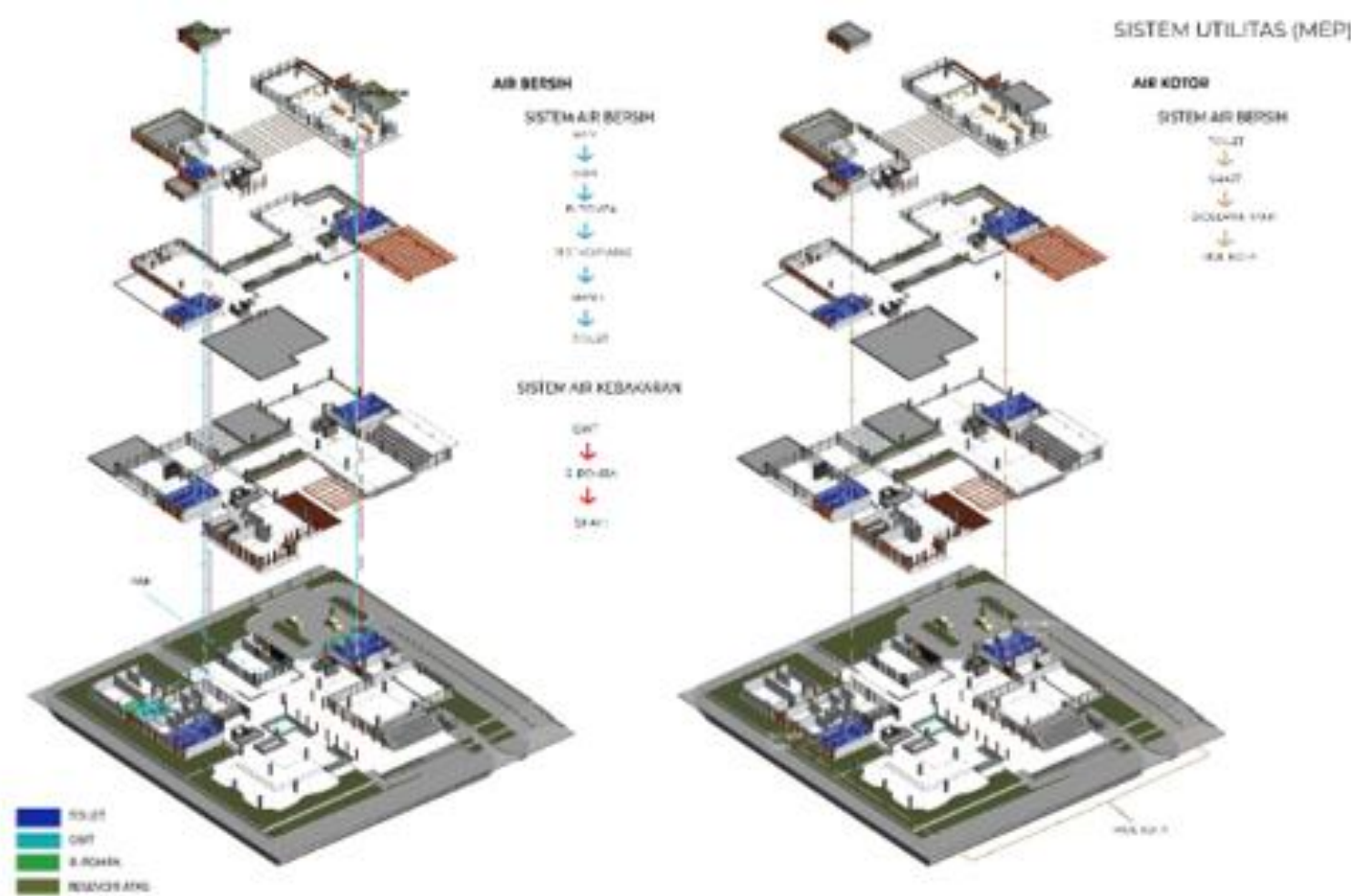

Gambar 14. Sistem Plumbing Bangunan.

Sumber: Penulis, 2019

Sirkulasi vertikal bangunan menggunakan tangga dan lift yang diperuntukan bagi penyandang disabilitas. Mayoritas pengudaraan bangunan menggunakan pengudaraan alami, ada beberapa ruangan menggunakan ac split sebagai penggunaannya tetapi memungkinan juga menggunakan pengudaraan alami. Sistem listrik berasal dari PLN dan disebarkan ke tiap lantai dengan cadangan listrik genset serta sistem plumbing berasal dari PAM dan di tampung di penampungan air pada bangunan dan disebarkan ke toilet pada tiap lantai dengan sistem air kotor langsung menuju riol kota dan diolah terlebih dahulu di bioseptic tank.

\section{Ruang Pembelajaran Kreativitas di BSD}

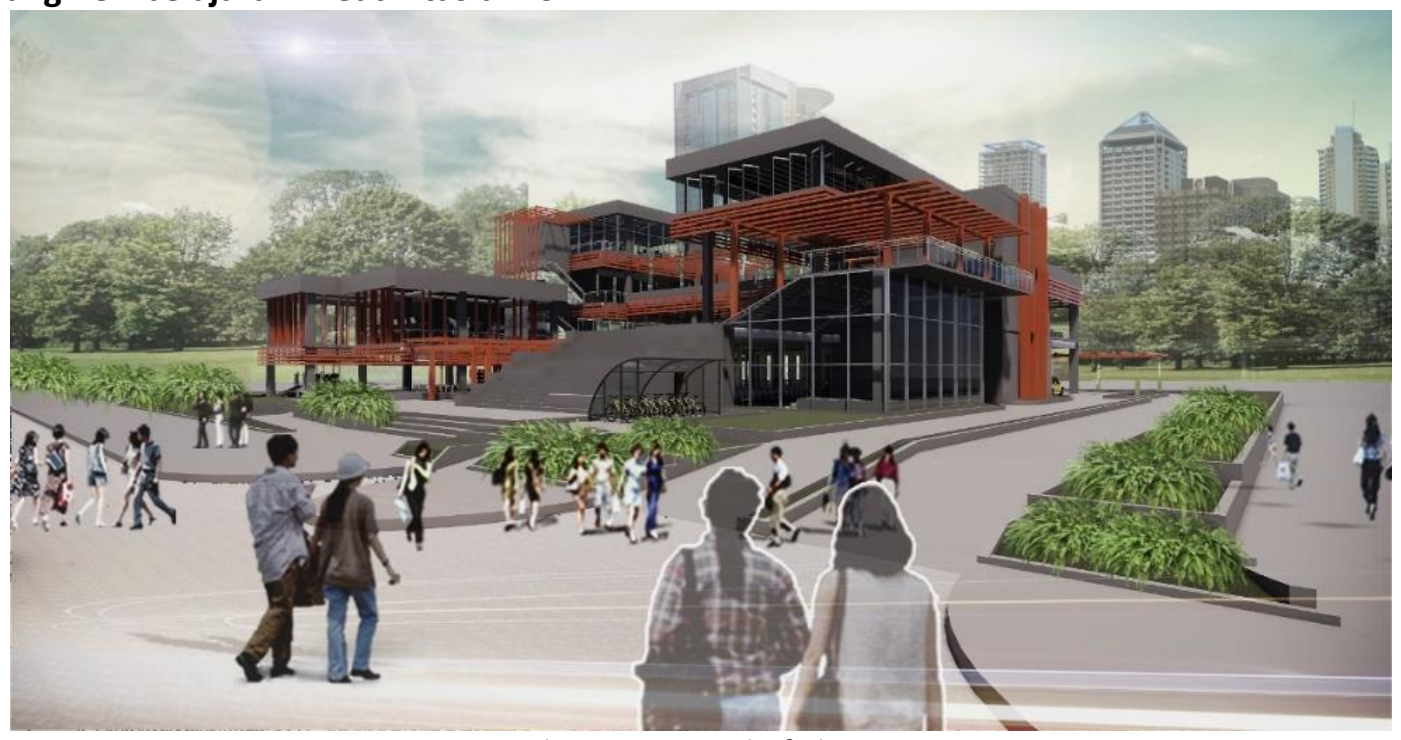

Gambar 15. Perspektif Eksterior

Sumber: Penulis, 2019 


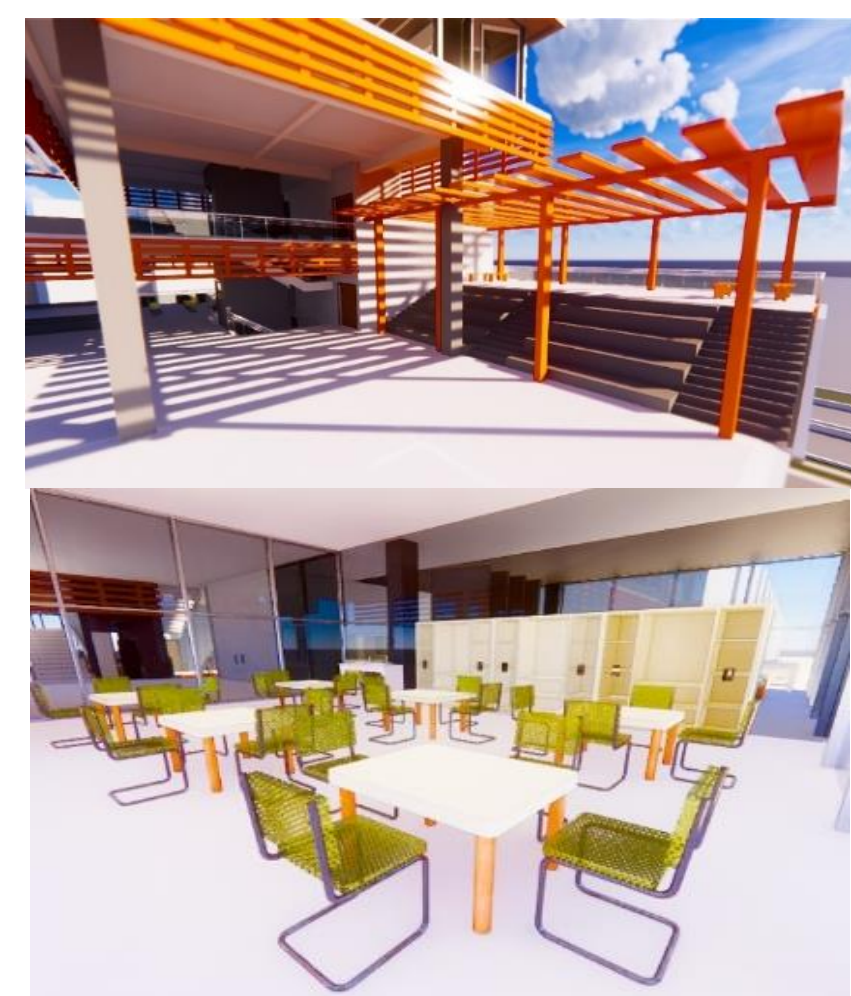

Gambar 16. Perspektif Eksterior Event Space dan Ruang Workshop Sumber: Penulis, 2019

\section{KESIMPULAN DAN SARAN}

Kawasan BSD merupakan kawasan maju yang masih dapat dikembangkan lagi. Dengan mayoritas masyarakat BSD merupakan masyarakat milenial menjadikan Ruang Pembelajaran Kreativitas ini dapat menjadi salah satu wadah third place. Dengan tujuan sebagai wadah bagi masyarakat dalam bersosialisasi, mengembangkan potensi diri di dalamnya terdapat program kesenian, kelas workshop, seminar, dan study room. Oleh karena itu, ruang ini diharapkan dapat menumbuhkan rasa sosial dan kreatif masyarakat melalui kegiatan-kegiatan di dalamnya.

\section{REFERENSI}

Departemen Pekerjaan Umum. (1979). Pedoman Perencanaan Lingkungan Permukiman. Jakarta.

Frf. (2016). Pengertian Kreativitas. Diakses 11 Desember 2019. http://mangihot.blogspot.com/2016/11/pengertian-kreativitas.html

Lobell, M. (1983). Spatial Archetypes. Revisions. Vol. 6, No.2, Fall, 69-82.

Loveday, Dr.T. (2008). Construction, the Third Space of Architecture. Australia.

Oldenburg, R. (1989). The Great Good Place. New York: Paragon House.

Shane, H.G. (1984). Arti Pendidikan bagi Masa Depan. Jakarta: Rajawali Pers

Soja, E. (1996). Thirdspace. USA: Blackwell Press.

Tjahjono, G. (2000). Metode Perancangan Suatu Pengantar untuk Arsitek dan Perancang. Depok: Universitas Indonesia.

Undang-Undang Republik Indonesia Nomor 20 Tahun 2003 tentang Sistem Pendidikan Nasional Wikipedia. Bumi Serpong Damai. Di akses 17 Juli 2019. https://id.wikipedia.org/wiki/Bumi_Serpong_Damai

Wikipedia. Serpong, Tangerang Selatan. Di akses 17 Juli 2019. https://id.wikipedia.org/wiki/Serpong,_Tangerang_Selatan

Yenita, R.T. (2015). Pengembangan Pendidikan Masa Depan. Di akses 17 Juli 2019. https://www.kompasiana.com/ratnatiwiy/55db2c44127b61ce0fc45664/pengembanganpendidikan-masa-depan?page=all. 